\title{
Effect of the $Y$ chromosome on testis weight in mice
}

\author{
Kunio SATOU ${ }^{1)}$ and Jun-ichi $\mathrm{SUTO}^{2) *}$ \\ ${ }^{1)}$ Center for Animal Disease Control and Prevention, National Institute of Animal Health, Tsukuba, Ibaraki 305-0856, Japan \\ 2) Agrogenomics Research Center, National Institute of Agrobiological Sciences, Tsukuba, Ibaraki 305-8634, Japan
}

(Received 19 August 2014/Accepted 2 February 2015/Published online in J-STAGE 15 February 2015)

ABSTRACT. We investigated the effect of the $\mathrm{Y}$ chromosome on testis weight in (B6.Cg- $A^{y} \times$ Y-consomic mouse strain) $\mathrm{F}_{1}$ male mice. We obtained the following results: (1) Mice with the Mus musculus domesticus-type Y chromosome had significantly heavier testis than those with the M. m. musculus-type Y chromosome. (2) Variations in Usp $9 y$ and the number of CAG repeats in Sry were significantly associated with testes weight. The $A^{y}$ allele was correlated with a reduced testis weight, and the extent of this reduction was significantly associated with a CAG repeat number polymorphism in Sry. These results suggest that Y chromosome genes not only influence testis weight but also modify the effect of the $A^{y}$ allele in mediating this phenomenon.

KEY WORDS: $A^{y}$ allele at the agouti locus, Sry CAG repeat number polymorphism, testis weight, Usp9y, Y-consomic strains

doi: 10.1292/jvms.14-0423; J. Vet. Med. Sci. 77(6): 753-759, 2015

Testis weight is an important reproductive trait in males, because of its direct connection with spermatogenic ability [14]. This highly heritable quantitative trait varies widely among inbred mouse strains [36]. Many studies have extensively explored the genes or loci that control testis weight in mice $[21,22,32,36,40]$, thus revealing many autosomal and $\mathrm{X}$-linked genetic effects. In contrast, Y-linked genetic effects have not yet attracted significant attention. Several studies have addressed the relationship between testis weight and the $\mathrm{Y}$ chromosome, the results of which were rather controversial [7, 15-17, 22, 36]. We suggest that these controversies arose due to the implementation of experiments that did not thoroughly control the autosomal and/or X-linked genetic variations. Therefore, we investigated the effect of the $\mathrm{Y}$ chromosome on testis weight in Y-chromosome-consomic (Y-consomic) mouse strains by making the potential genetic effects other than Y chromosome uniform [36]. We investigated 17 Y-consomic strains that were established in the inbred mouse strain DH/Sgn (DH). In the current study, we further investigated the effect of the Y chromosome on testis weight in genetic backgrounds that differed from those used in the previous study. It is most feasible to produce $F_{1}$ mice using the Y-consomic strains as sires to alter their genetic backgrounds. Therefore, we produced and analyzed $\mathrm{F}_{1}$ mice between B6.Cg- $A^{y}$ females and Y-consomic strain males. Because $A^{y}$ is an autosomal dominant allele and homozygous $A^{y} / A^{y}$ mice are lethal in utero [9], the living $A^{y}$ mice are invariably heterozygotes [9]. Thus, we can simultaneously utilize two different $\mathrm{F}_{1}$ genetic backgrounds (i.e., $\mathrm{F}_{1} A^{y}$ and $\mathrm{F}_{1}$ non- $A^{y}$ backgrounds). The $A^{y}$ allele is known to signifi-

*Correspondence to: Suto, J., Agrogenomics Research Center, National Institute of Agrobiological Sciences, Tsukuba, Ibaraki 305-8634, Japan. e-mail: jsuto@affrc.go.jp

(C)2015 The Japanese Society of Veterinary Science

This is an open-access article distributed under the terms of the Creative Commons Attribution Non-Commercial No Derivatives (by-nc-nd) License $<$ http://creativecommons.org/licenses/by-nc-nd/3.0/>. cantly reduce testis weight [34], and as such, this mating scheme allows us to examine this further by including the $A^{y}$ allele effect into the analyses as a potential autosomal effect.

The $A^{y}$ allele at the agouti locus causes obesity in mice [9]. In normal mice, the agouti gene is expressed only in the skin $[4,27]$ where it functions as an inverse agonist of the melanocortin 1 receptor to regulate pigmentation [23, 31]. However, in $A^{y}$ mice, the $A^{y}$ allele is associated with a large deletion, thus causing agouti gene expression to be aberrantly controlled by the unrelated Raly gene promoter [10, 25-27]. This leads to the ectopic overexpression; and therefore, $A^{y}$ mice have a yellow coat and develop maturity-onset obesity. The molecular bases underlying these phenotypes are well understood; however, those leading to the reduction in testis weight are still unknown [6, 18, 29].

The B6.Cg- $A^{y}$ strain was maintained at the National Institute of Agrobiological Sciences (NIAS, Tsukuba, Japan) along with the following Y-consomic strains: DH-Chr $\mathrm{Y}^{\mathrm{A}}\left(\mathrm{Y}\right.$ chromosome from A/J strain), DH-Chr $\mathrm{Y}^{\mathrm{AKR}}(\mathrm{AKR} / \mathrm{J})$, DH-Chr $\quad \mathrm{Y}^{\mathrm{B} 6}(\mathrm{C} 57 \mathrm{BL} / 6 \mathrm{~J}), \quad \mathrm{DH}-\mathrm{Chr} \quad \mathrm{Y}^{\mathrm{BALB}}(\mathrm{BALB} / \mathrm{cA})$, DH-Chr $\quad \mathrm{Y}^{\mathrm{C} 3 \mathrm{H}}(\mathrm{C} 3 \mathrm{H} / \mathrm{HeJ}), \quad \mathrm{DH}-\mathrm{Chr} \quad \mathrm{Y}^{\mathrm{CAS}}(\mathrm{CAST} / \mathrm{EiJ})$, DH-Chr $\quad \mathrm{Y}^{\mathrm{CBA}}(\mathrm{CBA} / \mathrm{N})$, DH-Chr $\quad \mathrm{Y}^{\mathrm{CF} 1}(\mathrm{CF} 1 / \mathrm{Sgn})$, DHChr $Y^{\mathrm{DBA}}(\mathrm{DBA} / 2 \mathrm{~J})$, DH-Chr $\mathrm{Y}^{\mathrm{DDD}}(\mathrm{DDD} / \mathrm{Sgn})$, DH-Chr $\mathrm{Y}^{\mathrm{DH}}(\mathrm{DH} / \mathrm{Sgn}), \mathrm{DH}-\mathrm{Chr} \mathrm{Y}^{\mathrm{KK}}(\mathrm{KK} / \mathrm{Ta}), \mathrm{DH}-\mathrm{Chr} \mathrm{Y}^{\mathrm{RF}}(\mathrm{RF} / \mathrm{J})$, DH-Chr $\quad \mathrm{Y}^{\mathrm{RR}}(\mathrm{RR} / \mathrm{Sgn}), \quad \mathrm{DH}-\mathrm{Chr} \quad \mathrm{Y}^{\mathrm{SJL}}(\mathrm{SJL} / \mathrm{J}), \quad \mathrm{DH}-\mathrm{Chr}$ $\mathrm{Y}^{\mathrm{SS}}(\mathrm{SS} / \mathrm{Sgn})$ and DH-Chr $\mathrm{Y}^{\mathrm{SWR}}(\mathrm{SWR} / \mathrm{J})$.

Males of each Y-consomic strain were crossed with B6.Cg- $A^{y}$ females to produce ( $+\mathrm{B} 6 . \mathrm{Cg}-A^{y} \times \jmath^{\top} \mathrm{DH}-\mathrm{Chr} \mathrm{Y}^{@}$ ) $\mathrm{F}_{1}$ strains (@ is an arbitrary inbred strain name). Thus, $\mathrm{F}_{1}$ mice comprised $\mathrm{F}_{1} A^{y}$ and $\mathrm{F}_{1}$ non- $A^{y}$ mice. Hereafter, we designated $\mathrm{F}_{1} A^{y}$ mice as $\mathrm{F}_{1}-\mathrm{Y}$ and $\mathrm{F}_{1}$ non- $A^{y}$ mice as $\mathrm{F}_{1}-\mathrm{A}$. Occasionally, the origin of the $\mathrm{Y}$ chromosome was specifically indicated for the $\mathrm{F}_{1}$ mice. For example, the $9 \mathrm{~B} 6 . \mathrm{Cg}-A^{y}$ $\times{ }^{1} \mathrm{DH}-\mathrm{Chr} \mathrm{Y}^{\mathrm{B} 6} \mathrm{~F}_{1}-\mathrm{Y}$ strain was designated as $\mathrm{F}_{1}-\mathrm{Y}\left(\mathrm{Y}^{\mathrm{B} 6}\right)$. $\mathrm{F}_{1}$ - $\mathrm{Y}$ mice were visually distinct from $\mathrm{F}_{1}-\mathrm{A}$ mice, because the former had a yellow coat [9]. Three to five male mice of the same strain, irrespective of $F_{1}-A$ or $F_{1}-Y$ mice, were housed in a single cage. The number of mice used in this 
study is summarized in Table 1. All mice were maintained in a specific-pathogen-free facility with a regular light cycle (12 hr light and $12 \mathrm{hr}$ dark) and controlled temperature and humidity. Food (CRF-1, Oriental Yeast Co., Ltd., Tokyo, Japan) and water were freely available throughout the experimental period. All animal procedures were approved by the Institutional Animal Care and Use Committee of NIAS, and experiments were conducted in accordance with the committee-approved guidelines.

At 16 weeks of age, the mice were weighed on an electric balance to the nearest $0.01 \mathrm{~g}$. They were euthanized by ether over dose, and their testes were removed and placed in physiological saline. After being rinsed and wiped with wet chromatography paper, the paired testes were weighed on the electric balance to the nearest $1 \mathrm{mg}$.

As mentioned above, the $A^{y}$ allele reduces testis weight in mice [34]. The degree of this reduction varied among our $\mathrm{F}_{1}$-Y strains. Therefore, the effect of the $A^{y}$ allele in reducing testis weight in each individual $\mathrm{F}_{1}-\mathrm{Y}$ mouse was defined as the "Tw ratio." For example, the "Tw ratio" in the $\mathrm{F}_{1}-\mathrm{Y}\left(\mathrm{Y}^{\mathrm{A}}\right)$ strain was calculated as follows:

Tw ratio $=\left(\right.$ Testis weight in each individual $\mathrm{F}_{1}-\mathrm{Y}\left(\mathrm{Y}^{\mathrm{A}}\right)$ mouse -Average testis weight in $\mathrm{F}_{1}-\mathrm{A}\left(\mathrm{Y}^{\mathrm{A}}\right)$ mice)/[Average testis weight in $\mathrm{F}_{1}-\mathrm{Y}\left(\mathrm{Y}^{\mathrm{DH}}\right)$ mice -Average testis weight in $\mathrm{F}_{1}-\mathrm{A}\left(\mathrm{Y}^{\mathrm{DH}}\right)$ mice]

We identified the following thirty single nucleotide polymorphisms (SNPs) in the 16 Y-consomic strains (DH-Chr $\mathrm{Y}^{\mathrm{DH}}$ was not genotyped) [36]: rs47359684, rs47900677, rs46080695, rs52139814, rs45850354, rs48064925, rs51995337, rs51133250, rs50647790, rs51277152, rs48685451, rs48834187, rs46947134, rs51756947, rs48554025, rs47574660, rs51766109, rs49468864, rs49623242, rs51230091, rs49614307, rs48926479, rs51025923, rs48512209, rs47293184, rs51685350, rs47616691, rs51560704, rs46643293 and rs51529727. We also identified the following nine polymorphisms in Sry (nt numbers are based on the GenBank entry X67204): nt 8491, nt 8701 , nt 8711 , nt 8731 , number of first CAG repeats starting at nt 8733, number of second CAG repeats starting at nt 8811, nt 8930, nt 8934 and nt 9006 [11]. Based on the Sry sequences, the DH-Chr Y ${ }^{\mathrm{A}}$, DH-Chr $\mathrm{Y}^{\mathrm{B} 6}$, DH-Chr $\mathrm{Y}^{\mathrm{BALB}}$, $\mathrm{DH}-\mathrm{Chr} \mathrm{Y}^{\mathrm{C} 3 \mathrm{H}}$, DH-Chr $\mathrm{Y}^{\mathrm{CBA}}$, DH-Chr $\mathrm{Y}^{\mathrm{CF} 1}, \mathrm{DH}-\mathrm{Chr} \mathrm{Y}^{\mathrm{DH}}$, DH-Chr $\mathrm{Y}^{\mathrm{KK}}, \mathrm{DH}-\mathrm{Chr} \mathrm{Y}^{\mathrm{RR}}$ and DH-Chr $\mathrm{Y}^{\mathrm{SS}}$ strains were defined as possessing the Mus musculus musculus-type Y chromosome (YMus), whereas the DH-Chr Y ${ }^{\mathrm{AKR}}$, DH-Chr $\mathrm{Y}^{\mathrm{DDD}}, \mathrm{DH}-\mathrm{Chr} \mathrm{Y}^{\mathrm{RF}}$, DH-Chr $\mathrm{Y}^{\mathrm{SJL}}$ and DH-Chr $\mathrm{Y}^{\mathrm{SWR}}$ strains were defined as possessing the $M . m$. domesticus-type $\mathrm{Y}$ chromosome $\left(\mathrm{Y}^{\mathrm{Dom}}\right)$. The strains, $\mathrm{Y}^{\mathrm{Mus}} \mathrm{vs}$. $\mathrm{Y}^{\mathrm{Dom}}$, were classified on the basis of the following criteria: (1) a C-to-T transitional substitution at nt 8491 in the high mobility group (HMG) box of Sry ( $\mathrm{Y}^{\mathrm{Mus}=\mathrm{T}}$ and $\left.\mathrm{Y}^{\mathrm{Dom}}=\mathrm{C}\right)[20]$ and $(2)$ the presence of a C-to- $\mathrm{T}$ change that created a TAG termination codon at nt 9006 in the third major CAG repeat starting at nt 8985 in $Y^{\text {Dom }}$ [8] but not $\mathrm{Y}^{\text {Mus }}$ (the mouse Sry gene has four major sites comprising approximately $10 \mathrm{CAG}$ repeats). The partitioning of the strains into either $\mathrm{Y}^{\mathrm{Mus}}$ or $\mathrm{Y}^{\mathrm{Dom}}$ was compatible with the descriptions set forth in previous studies $[2,28]$.
Table 1. Number of $\mathrm{F}_{1}$ mice and their average body weight

\begin{tabular}{|c|c|c|}
\hline $\begin{array}{l}\text { Y chromosome } \\
\text { donor strain } \\
\text { (abbreviation) }\end{array}$ & $\begin{array}{c}\text { Number of } \mathrm{F}_{1} \text {-A mice } \\
(\text { mean } \pm \mathrm{SE} \\
\text { body weight, } \mathrm{g})\end{array}$ & $\begin{array}{c}\text { Number of } \mathrm{F}_{1}-\mathrm{Y} \text { mice } \\
(\text { mean } \pm \mathrm{SE} \\
\text { body weight, } \mathrm{g})\end{array}$ \\
\hline $\mathrm{A} / \mathrm{J}(\mathrm{A})$ & $18(33.32 \pm 0.91)$ & $12(47.04 \pm 0.98)$ \\
\hline AKR/J (AKR) & $5(31.91 \pm 1.05)$ & $13(44.18 \pm 0.56)$ \\
\hline $\mathrm{C} 57 \mathrm{BL} / 6 \mathrm{~J}(\mathrm{~B} 6)$ & $17(33.96 \pm 0.66)$ & $18(46.49 \pm 0.78)$ \\
\hline BALB/cA (BALB) & $7(35.77 \pm 1.93)$ & $13(48.43 \pm 0.76)$ \\
\hline $\mathrm{C} 3 \mathrm{H} / \mathrm{HeJ}(\mathrm{C} 3 \mathrm{H})$ & $8(35.51 \pm 2.05)$ & $15(47.11 \pm 0.64)$ \\
\hline CAST/EiJ (CAS) & $12(34.47 \pm 0.37)$ & $12(47.97 \pm 0.58)$ \\
\hline $\mathrm{CBA} / \mathrm{N}(\mathrm{CBA})$ & $12(36.06 \pm 0.54)$ & $10(49.09 \pm 0.94)$ \\
\hline $\mathrm{CF} \# 1 / \mathrm{Sgn}$ (CF1) & $12(35.86 \pm 0.83)$ & $10(49.10 \pm 0.97)$ \\
\hline $\mathrm{DBA} / 2 \mathrm{~J}(\mathrm{DBA})$ & $11(32.91 \pm 0.36)$ & $13(46.28 \pm 0.66)$ \\
\hline DDD/Sgn (DDD) & $15(36.32 \pm 0.59)$ & $13(47.72 \pm 0.57)$ \\
\hline $\mathrm{DH} / \mathrm{Sgn}(\mathrm{DH})$ & $9(34.20 \pm 0.99)$ & $10(46.93 \pm 0.84)$ \\
\hline $\mathrm{KK} / \mathrm{Ta}(\mathrm{KK})$ & $16(29.69 \pm 0.47)^{\mathrm{a})}$ & $12(41.46 \pm 0.95)^{\mathrm{a})}$ \\
\hline $\mathrm{RF} / \mathrm{J}(\mathrm{RF})$ & $8(33.29 \pm 1.29)$ & $10(48.44 \pm 0.62)$ \\
\hline RR/Sgn (RR) & $13(32.27 \pm 0.41)$ & $11(45.99 \pm 0.50)$ \\
\hline $\mathrm{SJL} / \mathrm{J}(\mathrm{SJL})$ & $16(35.60 \pm 1.01)$ & $17(47.62 \pm 0.58)$ \\
\hline SS/Sgn (SS) & $18(32.09 \pm 0.70)$ & $17(45.44 \pm 0.64)$ \\
\hline SWR/J (SWR) & $10(33.60 \pm 0.50)$ & $12(45.69 \pm 0.48)$ \\
\hline
\end{tabular}

a) According to the Dnnett's multiple comparison test using DH as a reference, strain carrying $\mathrm{Y}^{\mathrm{KK}}$ was significantly associated with reduced body weight in both $\mathrm{F}_{1}-\mathrm{A}$ and $\mathrm{F}_{1}-\mathrm{Y}$ mice [37].

Y-linked genetic variations controlling testis weight were identified using the following three-step approach [36]: (1) The effects of genes on autosomes and the X chromosome were eliminated by the use of Y-consomic strains, and the net phenotypic effects of Y-linked genes were assessed. (2) Either Dunnett's multiple comparison test (with the background DH strain as a reference) or the Tukey-Kramer honest significant difference (HSD) test was used to determine if a trait was Y-linked. (3) The data from all strains were assembled on the basis of SNP genotypes, and the statistical significance of the differences was assessed. Two groups partitioned by genotype were compared using the Student's or Welch's $t$-test, and three groups were compared with oneway analysis of variance (ANOVA). Based on the number of SNP loci (n) genotyped, the significant threshold $P$ value was determined as $0.05 / \mathrm{n}$ with the Bonferroni correction test. Unless otherwise noted, $P<0.05$ was considered statistically significant.

Testis weight showed a bell-shaped distribution curve for both $\mathrm{F}_{1}$-A and $\mathrm{F}_{1}-\mathrm{Y}$ mice, but did not show a normal distribution on the basis of the Shapiro-Wilk W test (JMP8, SAS Institute Japan Inc., Tokyo, Japan). Therefore, the Box-Cox method was used to normalize the data prior to subsequent statistical analyses. According to Dunnett's multiple comparison tests, a Y chromosome substitution caused $Y^{\mathrm{SJL}}$ and $\mathrm{Y}^{\mathrm{CAS}}$ strains to have significantly heavier testis than the $\mathrm{Y}^{\mathrm{DH}}$ strain in $\mathrm{F}_{1}$-A mice, and the $\mathrm{Y}^{\mathrm{CAS}}$ strain to have significantly heavier testis than the $\mathrm{Y}^{\mathrm{DH}}$ strain in $\mathrm{F}_{1}$-Y mice (Fig. 1).

The mean testis weight $\pm \mathrm{SE}$ in $\mathrm{F}_{1}$-A mice was 247.0 $\pm 1.4 \mathrm{mg}(\mathrm{n}=208)$, and that in $\mathrm{F}_{1}-\mathrm{Y}$ mice was $214.5 \pm 1.0$ $\mathrm{mg}(\mathrm{n}=218)$, the difference of which was highly significant $\left(P=1.09 \times 10^{-60}\right)$. Thus, consistent with our previous finding, 


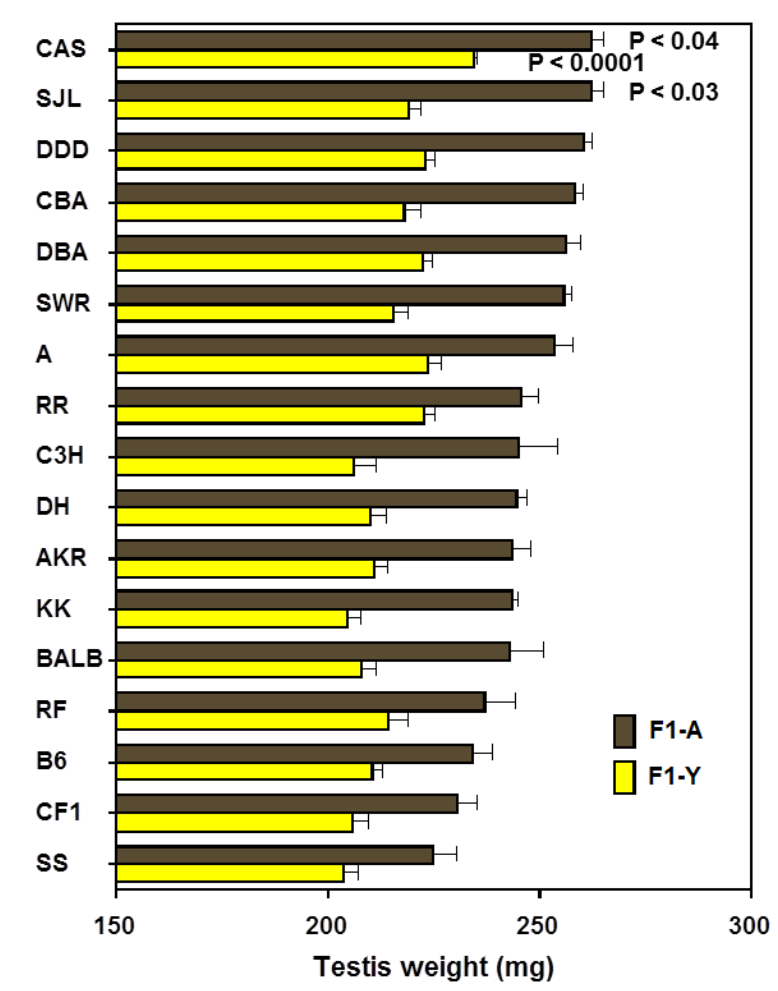

Fig. 1. Distribution of mean testis weight with $\mathrm{SE}$ in $\mathrm{F}_{1}-\mathrm{A}$ and $\mathrm{F}_{1}$-Y strains. Each strain symbol on the $\mathrm{y}$-axis represents the kind of Y-chromosome donor strain; for example, "C3H" represents $\mathrm{F}_{1}-\mathrm{A}$ and $\mathrm{F}_{1}-\mathrm{Y}$ mice carrying the $\mathrm{Y}$ chromosome of $\mathrm{C} 3 \mathrm{H}$ strain. Strain symbols were sorted in descending order according to the mean testis weight of $\mathrm{F}_{1}$-A strain. Statistical comparisons were made with Dunnett's multiple comparison tests using $\mathrm{Y}^{\mathrm{DH}}$ as a reference. $\mathrm{F}_{1}-\mathrm{A}$ and $\mathrm{F}_{1}$-Y strains were analyzed separately.

the $A^{y}$ allele reduced testis weight.

Y-linked SNPs and Sry polymorphisms could be summarized into six polymorphic patterns (Table 2). Although we performed statistical analyses on these data, the significance threshold at $\alpha=0.05$ was $0.0013(0.05 / 39)$, because we actually genotyped 39 polymorphisms.

rs48685451 in $K d m 5 d$ and additional 25 SNPs had the same polymorphic pattern, which was consistent with the distinction between $Y^{\text {Mus }}$ and $Y^{\text {Dom }}$. When the $F_{1}-A$ and $F_{1}-Y$ mice were analyzed separately, only $F_{1}-A$ mice showed a significant association with testis weight (Table 3). However, because two-way ANOVA showed no statistically significant interactions between the agouti locus genotype (A or Y) and the rs48685451 genotype (A or G), data on $\mathrm{F}_{1}$-A and $\mathrm{F}_{1}-\mathrm{Y}$ mice were combined and analyzed after standardization within each $\mathrm{F}_{1}$ type. As a result, rs48685451 was significantly associated with testis weight. Mice with the A allele $\left(\mathrm{Y}^{\mathrm{Dom}}\right)$ had significantly heavier testis than mice with the $\mathrm{G}$ allele ( $\mathrm{Y}^{\mathrm{Mus}}$ ), which is in accordance with our previous findings [36]. Subsequent analyses were performed in a similar manner.

rs51766109 in Usp9y was significantly associated with testis weight, and mice with the $\mathrm{T}$ allele had significantly heavier testis than those with the $\mathrm{C}$ allele. The result differed with our previous study in which rs51766109 had no significant effect on absolute testis weight [36]. rs46947134 in Uty was not significantly associated with testis weight. The result also differed with our previous study in which rs46947134 had significant effect on absolute testis weight [36]. A major difference between the two studies is the strain of mice used (i.e., our previous study used DH-Chr $\mathrm{Y}^{\mathrm{a}}$ strains, whereas the present study was conducted with $\mathrm{B} 6 . \mathrm{Cg}-A^{y} \times \mathrm{DH}-\mathrm{Chr}$ $\mathrm{Y} @ \mathrm{~F}_{1}$ strains). Thus, this suggests that the effect of the $\mathrm{Y}$ chromosome on testis weight was considerably influenced by genetic backgrounds. This result is not surprising, because genes on the $\mathrm{X}$ chromosome, in mitochondria, and half of all autosomes were thoroughly replaced by the $\mathrm{B} 6$ genome in $\mathrm{F}_{1}$ male mice. Indeed, there is evidence that the Y chromosome interacts with the $\mathrm{X}$-linked locus in controlling testis weight [36]. In addition, testis weight measurements were taken on 16-week-old mice in the present study and 80-day-old mice in our previous study, suggesting that the discrepancies between the two studies were partly due to the difference in the ages of the mice investigated. QTLs for testis weight have been shown to vary between pigs of different ages [30]. Alternatively, it is possible that the discrepancies between two studies are caused by the differences in epigenomes.

Uty and Usp9y are histocompatibility Y antigen-coding genes. Both genes are expressed extensively in testis; however, physiological significance of them remains unknown. For example, Usp9y has been implicated in human infertility associated with oligospermia and azoospermia [19, 33]; however, a more recent study demonstrated that the Usp $9 y$ is not essential for normal spermatogenesis [24]. Several lines of evidence suggest that Uty and Usp $9 y$ have roles in cell division, proliferation and/or differentiation [13, 39]; therefore, it is possible that they control testis mass through these physiological processes.

Nucleotides at positions 8491 and 8711 in Sry were significantly associated with testis weight. Mice with the $\mathrm{C}$ allele had significantly heavier testis than mice with the $\mathrm{T}$ allele at both sites. As with rs48685451 in $K d m 5 d$, Sry polymorphisms at these positions were mostly consistent with the distinction between $\mathrm{Y}^{\mathrm{Mus}}$ and $\mathrm{Y}^{\mathrm{Dom}}$. In this case, $\mathrm{Y}^{\mathrm{CAS}}$ was classified in $Y^{\text {Dom }}$. In the case of rs48685451 in Kdm5d and others, $\mathrm{Y}^{\mathrm{CAS}}$ was classified in $\mathrm{Y}^{\mathrm{Mus}}$, and according to the literature [1], $\mathrm{Y}^{\mathrm{CAS}}$ was classified as $\mathrm{Y}^{\mathrm{Mus}}$.

Starting at nt 8733 , the number of the first major CAG repeats in Sry was significantly associated with testis weight. Mice with 11 repeats had significantly lighter testis than mice with 9 or 12 repeats. In contrast, starting at nt 8811 , the number of the second major CAG repeats was not significantly associated with testis weight. In mice, Sry contains four large CAG trinucleotide repeat regions, resulting in four major polyglutamine stretches [8]. The C-to-T transitional substitution at nt 9006 creates a premature TAG termination codon in the third major CAG repeat region of $\mathrm{Y}^{\mathrm{Dom}}$. Therefore, polymorphisms in the first and second CAG repeats are potentially important. Consistent with our previous findings [36], the present study demonstrated that variation in the number of CAG repeats starting at nt 8733 of Sry was sig- 
Table 2. Patterns of SNPs and Sry polymorphisms in Y-consomic strains

\begin{tabular}{|c|c|c|c|c|c|c|c|c|c|c|c|c|c|c|c|c|c|}
\hline Gene & $\mathrm{SNP} /$ polymorphism & $\mathrm{A}$ & B6 & BALB & $\mathrm{C} 3 \mathrm{H}$ & $\mathrm{CBA}$ & CF1 & DBA & KK & $\mathrm{RR}$ & SS & CAS & AKR & DDD & $\mathrm{RF}$ & SJL & SWR \\
\hline$\overline{K d m 5 d}$ & rs48685451 ${ }^{\text {a) }}$ & G & $\mathrm{G}$ & G & G & G & G & G & G & G & $\mathrm{G}$ & G & A & A & $\mathrm{A}$ & A & A \\
\hline Usp9y & rs51766109 & $\mathrm{C}$ & $\mathrm{C}$ & $\mathrm{C}$ & $\mathrm{T}$ & $\mathrm{T}$ & $\mathrm{C}$ & $\mathrm{T}$ & $\mathrm{C}$ & $\mathrm{T}$ & $\mathrm{C}$ & $\mathrm{T}$ & $\mathrm{T}$ & $\mathrm{T}$ & $\mathrm{T}$ & $\mathrm{T}$ & $\mathrm{T}$ \\
\hline Uty & rs46947134 & $\mathrm{C}$ & $\mathrm{C}$ & $\mathrm{C}$ & G & G & $\mathrm{C}$ & G & $\mathrm{C}$ & G & $\mathrm{C}$ & $\mathrm{C}$ & $\mathrm{C}$ & $\mathrm{C}$ & $\mathrm{C}$ & $\mathrm{C}$ & $\mathrm{C}$ \\
\hline Sry & Nts at 8491 and $8711^{\text {b) }}$ & $\mathrm{T}$ & $\mathrm{T}$ & $\mathrm{T}$ & $\mathrm{T}$ & $\mathrm{T}$ & $\mathrm{T}$ & $\mathrm{T}$ & $\mathrm{T}$ & $\mathrm{T}$ & $\mathrm{T}$ & $\mathrm{C}$ & $\mathrm{C}$ & $\mathrm{C}$ & $\mathrm{C}$ & $\mathrm{C}$ & $\mathrm{C}$ \\
\hline Sry & $\begin{array}{l}\text { No. of CAG repeats } \\
\text { starting at nt } 8733\end{array}$ & 11 & 11 & 11 & 12 & 12 & 11 & 12 & 11 & 12 & 11 & 11 & 9 & 9 & 9 & 9 & 9 \\
\hline Sry & $\begin{array}{l}\text { No. of CAG repeats } \\
\text { starting at nt } 8811\end{array}$ & 12 & 12 & 12 & 10 & 10 & 12 & 10 & 12 & 10 & 12 & 12 & 13 & 12 & 13 & 12 & 12 \\
\hline
\end{tabular}

a) In addition to rs 48685451 in $K d m 5 d$, many SNPs showed similar polymorphic pattern [28]. b) Nt position is based on the numbering of GenBank entry X67204.

Table 3. Effects of gene polymorphisms on testis weight in Y-consomic strains

\begin{tabular}{|c|c|c|c|c|c|}
\hline \multirow{2}{*}{$\begin{aligned} \begin{array}{c}\text { SNP/Polymorphism } \\
\text { (Gene) }\end{array} \\
\text { rs48685451 }\end{aligned}$} & \multirow[t]{2}{*}{ Mice } & \multicolumn{3}{|c|}{ Paired testis weight $(\mathrm{mg}, \text { mean } \pm \mathrm{SE})^{\mathrm{a})}$} & \multirow[t]{2}{*}{$P$ value ${ }^{\mathrm{b})}$} \\
\hline & & A & G & & \\
\hline \multirow[t]{3}{*}{$(K d m 5 d)$} & $\mathrm{F}_{1}-\mathrm{A}$ & $254.9 \pm 2.1(n=54)$ & $244.2 \pm 1.7(n=144)$ & & 0.00023 \\
\hline & $\mathrm{F}_{1}-\mathrm{Y}$ & $216.8 \pm 1.6(\mathrm{n}=65)$ & $213.8 \pm 1.3(\mathrm{n}=143)$ & & NS (0.24) \\
\hline & Combined $\mathrm{F}_{1}$ & $0.268 \pm 0.076$ & $-0.096 \pm 0.063$ & & 0.00090 \\
\hline rs51766109 & & $\mathrm{C}$ & $\mathrm{T}$ & & \\
\hline \multirow[t]{3}{*}{ (Usp9y) } & $\mathrm{F}_{1}-\mathrm{A}$ & $238.1 \pm 2.3(\mathrm{n}=88)$ & $254.3 \pm 1.5(\mathrm{n}=110)$ & & $2.52 \times 10^{-9}$ \\
\hline & $\mathrm{F}_{1}-\mathrm{Y}$ & $209.1 \pm 1.5(\mathrm{n}=82)$ & $218.4 \pm 1.3(\mathrm{n}=126)$ & & $1.63 \times 10^{-6}$ \\
\hline & Combined $\mathrm{F}_{1}$ & $-0.415 \pm 0.078$ & $0.317 \pm 0.058$ & & $1.09 \times 10^{-13}$ \\
\hline rs46947134 & & $\mathrm{C}$ & G & & \\
\hline \multirow[t]{3}{*}{$(U t y)$} & $\mathrm{F}_{1}-\mathrm{A}$ & $245.9 \pm 1.7(n=154)$ & $251.5 \pm 2.5(n=44)$ & & NS (0.12) \\
\hline & $F_{1}-Y$ & $214.2 \pm 1.2(\mathrm{n}=159)$ & $216.7 \pm 2.2(\mathrm{n}=49)$ & & NS $(0.26)$ \\
\hline & Combined $\mathrm{F}_{1}$ & $-0.041 \pm 0.058$ & $0.184 \pm 0.099$ & & NS $(0.058)$ \\
\hline Nts at nt 8491 and 8711 & & $\mathrm{C}$ & $\mathrm{T}$ & & \\
\hline \multirow[t]{3}{*}{ (Sry) } & $\mathrm{F}_{1}-\mathrm{A}$ & $256.3 \pm 1.8(\mathrm{n}=66)$ & $242.6 \pm 1.8(\mathrm{n}=132)$ & & $4.01 \times 10^{-7}$ \\
\hline & $F_{1}-Y$ & $219.6 \pm 1.5(\mathrm{n}=77)$ & $211.9 \pm 1.3(\mathrm{n}=131)$ & & 0.00016 \\
\hline & Combined $\mathrm{F}_{1}$ & $0.403 \pm 0.070$ & $-0.203 \pm 0.064$ & & $4.07 \times 10^{-9}$ \\
\hline No. of CAG repeats starting at nt 8733 & & 9 & 11 & 12 & \\
\hline \multirow[t]{3}{*}{$($ Sry $)$} & $\mathrm{F}_{1}-\mathrm{A}$ & $254.9 \pm 2.1(\mathrm{n}=54)$ & $241.0 \pm 2.2(\mathrm{n}=100)$ & $251.5 \pm 2.5(n=44)$ & $4.36 \times 10^{-5}$ \\
\hline & $F_{1}-Y$ & $216.8 \pm 1.6(\mathrm{n}=65)$ & $212.3 \pm 1.6(\mathrm{n}=94)$ & $216.7 \pm 2.2(n=49)$ & NS (0.12) \\
\hline & Combined $\mathrm{F}_{1}$ & $0.268 \pm 0.090$ & $-0.231 \pm 0.071$ & $0.184 \pm 0.102$ & $1.65 \times 10^{-5}$ \\
\hline \multirow{4}{*}{$\begin{array}{l}\text { No. of CAG repeats starting at nt } 8811 \\
\text { (Sry) }\end{array}$} & & 10 & 12 & 13 & \\
\hline & $\mathrm{F}_{1}-\mathrm{A}$ & $251.5 \pm 2.5(\mathrm{n}=44)$ & $246.5 \pm 1.8(\mathrm{n}=141)$ & $239.4 \pm 4.9(\mathrm{n}=13)$ & NS $(0.11)$ \\
\hline & $F_{1}-Y$ & $216.7 \pm 2.2(\mathrm{n}=49)$ & $214.5 \pm 1.3(n=136)$ & $212.4 \pm 2.7(n=23)$ & NS $(0.39)$ \\
\hline & Combined $\mathrm{F}_{1}$ & $0.184 \pm 0.104$ & $-0.016 \pm 0.060$ & $-0.234 \pm 0.168$ & NS $(0.080)$ \\
\hline
\end{tabular}

a) Combined data are expressed as standardized values. b) NS, not significant.

nificantly associated with testis weight. However, although testis weight was inversely correlated with the numbers of CAG repeats in our previous study, here we show that the testis was significantly lighter only in mice with $11 \mathrm{CAG}$ repeats. Furthermore, although variation in the numbers of CAG repeats starting at nt 8811 of $S r y$ was significantly associated with testis weight in our previous study [36], no significant association was observed in this study. We cannot presently explain these discrepancies between the two studies, but we speculate that they are caused by differences in genetic backgrounds, ages and/or epigenomes.

When the $F_{1}$-A strains were sorted in descending order with regard to their testis weight, the testis weight of the $\mathrm{F}_{1}$-Y strains was not necessarily sorted in descending order
(Fig. 1). That is, the effect of the $A^{y}$ allele in reducing testis weight differed depending on Y chromosome type. Because there was variation in the $\mathrm{Tw}$ ratio among Y-consomic strains based on the Tukey-Kramer HSD test (Fig. 2), we performed association studies on the Tw ratio. The number of first major Sry CAG repeats (starting at nt 8733) was significantly associated with Tw ratio (Table 4). Mice with 11 repeats had a significantly lower Tw ratio than mice with 9 or 12 repeats. Thus, CAG repeat number polymorphism of Sry modified the effect of the $A^{y}$ allele in reducing testis weight.

$S r y$ is expressed in the gonad and plays roles in testis determination. On the basis of the findings on B6. $Y^{\text {Dom }}$ sex reversal [12], $Y^{\text {Dom }}$ can be classified into several functional classes. That is, $\mathrm{Y}^{\mathrm{Dom}}$ associated with either of (1) complete 


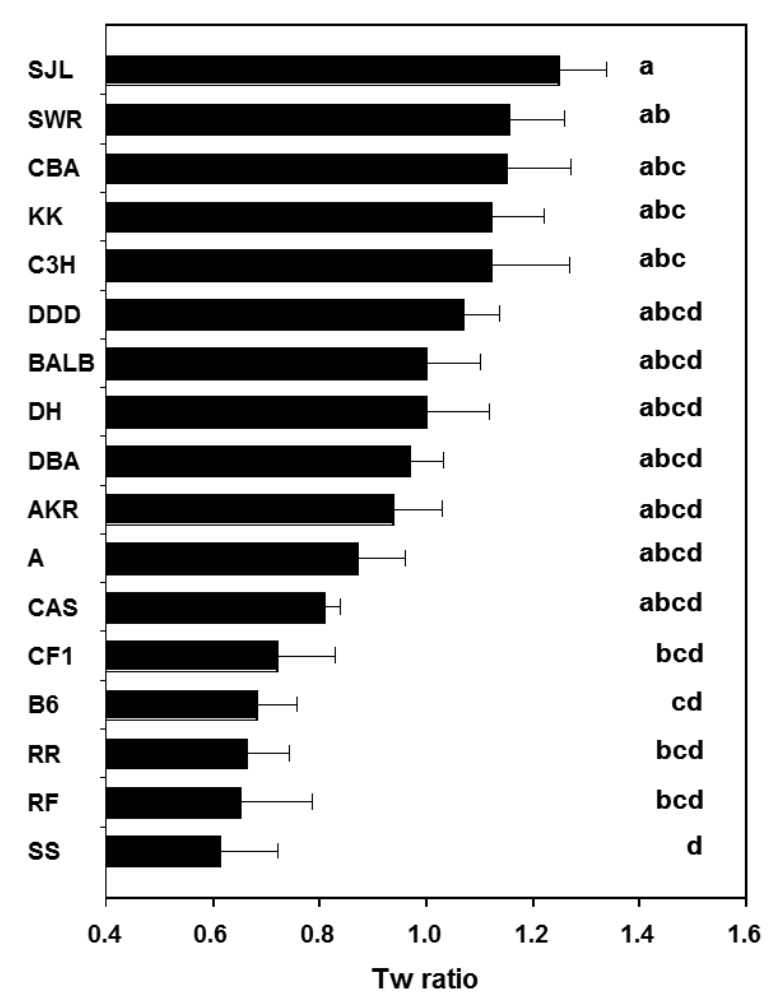

Fig. 2. Distribution of mean Tw ratio with $\mathrm{SE}$ in $\mathrm{F}_{1}-\mathrm{Y}$ strains. Each strain symbol on the $y$-axis represents the kind of Y-chromosome donor strain; for example, "C $3 \mathrm{H}$ " represents $\mathrm{F}_{1}-\mathrm{Y}$ mice carrying the $\mathrm{Y}$ chromosome of $\mathrm{C} 3 \mathrm{H}$ strain. Strain symbols were sorted in descending order according to the mean Tw ratio. Statistical comparisons were made with the Tukey-Kramer HSD tests. Values with different superscripts differ significantly.

sex reversal, (2) partial (fetal) sex reversal/hermaphrodism and (3) normal testis development [8, 12]. Coward et al. [8] once proposed a hypothesis that the degrees of sex reversal phenotype depend on polymorphism of CAG trinucleotide repeat of Sry. It has been known that many human genetic disorders are associated with polyglutamine stretch expansion (OMIM, Online inheritance in man, http://www.ncbi. nlm.nih.gov/omim). Although the hypothesis by Coward et al. was denied later [5], it was important that they indicated a genetic link between CAG repeat number polymorphism and gonadal phenotypes of mice. According to Bowles et al. [3], the presence of CAG repeats in the mouse Sry is essential for testis determination. They consider that the absolute sequence and length of the CAG repeat domain are not necessarily critical to its function; however, it has not yet been proved enough. We would like to propose that the CAG repeat polymorphism has roles in other physiological processes including the control of testis weight.

The above-mentioned analyses were based on the alleles at SNPs/Sry. We further performed analyses based on the strains partitioned by Y-linked haplotypes on the basis of the six SNPs and Sry polymorphisms (Table 2). $F_{1}$ mice were partitioned into five groups (Table 5). There was a significant difference in testis weight among the five groups in $\mathrm{F}_{1}$-A $\left(P=4.57 \times 10^{-11}\right)$ and $\mathrm{F}_{1}-\mathrm{Y}\left(P=3.44 \times 10^{-11}\right)$ mice. TukeyKramer HSD tests were used to compare testis weight among the five haplotype-based groups. A significant difference was observed between several pairs of groups. Group 4, which comprised only mice with $\mathrm{Y}^{\mathrm{CAS}}$, had the heaviest testis among five groups in both $\mathrm{F}_{1}$ mice. For Tw ratio, there were significant differences among the five groups $(P=0.000036)$. Tukey-Kramer HSD tests were used to compare testis weight among the five haplotype-based groups. Although there was no significant difference between Groups 1 and 5, Group 1 had the largest Tw ratio among the five groups and had a significantly larger Tw ratio than Groups 2, 3 and 4. Thus, the different aspects related to the effect of the Y chromosome on testis weight were elucidated only after the Y-consomic strains were analyzed by partitioning on the basis of Y-linked haplotypes.

Finally, we would like to mention the spermatogenic ability of mice used in this study. We have confirmed that all DH-Chr ${ }^{@}$ strains breed well in their brother-sister mating. $\left(\mathrm{B} 6 \times \mathrm{KK} . \mathrm{Cg}-A^{y}\right) \mathrm{F}_{1} A^{y}$ and $\left(\mathrm{B} 6 \times \mathrm{DDD} . \mathrm{Cg}-A^{y}\right) \mathrm{F}_{1} A^{y}$ males as well as their $\mathrm{F}_{1}$ non- $A^{y}$ littermate males are fully fertile

Table 4. Effects of gene polymorphisms on Tw ratio

\begin{tabular}{|c|c|c|c|c|}
\hline \multirow{2}{*}{$\begin{array}{l}\text { SNP/Polymorphism (Gene) } \\
\text { rs } 48685451\end{array}$} & \multicolumn{3}{|c|}{ Tw ratio $($ mean $\pm \mathrm{SE})$} & \multirow[t]{2}{*}{$P$ value $^{\text {a) }}$} \\
\hline & $\mathrm{A}$ & G & & \\
\hline$(K d m 5 d)$ & $1.04 \pm 0.05(\mathrm{n}=65)$ & $0.87 \pm 0.03(\mathrm{n}=143)$ & & NS (0.0049) \\
\hline rs51766109 & $\mathrm{C}$ & $\mathrm{T}$ & & \\
\hline (Usp9y) & $0.81 \pm 0.04(\mathrm{n}=82)$ & $1.00 \pm 0.04(\mathrm{n}=126)$ & & NS $(0.0015)$ \\
\hline rs46947134 & $\mathrm{C}$ & G & & \\
\hline (Uty) & $0.91 \pm 0.03(\mathrm{n}=159)$ & $0.98 \pm 0.06(\mathrm{n}=49)$ & & NS $(0.27)$ \\
\hline Nts at nt 8491 and 8711 & $\mathrm{C}$ & $\mathrm{T}$ & & \\
\hline$($ Sry) & $1.01 \pm 0.05(\mathrm{n}=77)$ & $0.88 \pm 0.04(\mathrm{n}=131)$ & & NS $(0.025)$ \\
\hline No. of CAG repeats starting at nt 8733 & 9 & 11 & 12 & \\
\hline$($ Sry $)$ & $1.04 \pm 0.05(\mathrm{n}=65)$ & $0.81 \pm 0.04(\mathrm{n}=94)$ & $0.98 \pm 0.06(n=49)$ & 0.0011 \\
\hline No. of CAG repeats starting at nt 8811 & 10 & 12 & 13 & \\
\hline$($ Sry $)$ & $0.98 \pm 0.06(\mathrm{n}=49)$ & $0.92 \pm 0.03(\mathrm{n}=136)$ & $0.81 \pm 0.08(\mathrm{n}=23)$ & NS $(0.25)$ \\
\hline
\end{tabular}

a) NS, not significant. 
Table 5. Testis weight and Tw ratio in Y-consomic strains partitioned by haplotypes based on Y-linked SNPs and Sry polymorphisms

\begin{tabular}{|c|c|c|c|c|}
\hline \multirow[t]{2}{*}{ Group } & \multirow[t]{2}{*}{ Strain } & \multicolumn{2}{|c|}{$\begin{array}{l}\text { Testis weight }(\mathrm{mg} \text {, mean } \pm \mathrm{SE})^{1)} \\
\quad \text { (Sample size) }\end{array}$} & \multirow{2}{*}{$\begin{array}{l}\text { Tw ratio }(\mathrm{mg}, \text { mean } \pm \mathrm{SE})^{\mathrm{a})} \\
\quad \text { (Sample size) }\end{array}$} \\
\hline & & $\mathrm{F}_{1}$-A mice & $\mathrm{F}_{1}-\mathrm{Y}$ mice & \\
\hline 1 & $\begin{array}{l}\text { DDD } \\
\text { SJL } \\
\text { SWR }\end{array}$ & $\begin{array}{c}259.8 \pm 1.6^{\mathrm{A}} \\
(\mathrm{n}=41)\end{array}$ & $\begin{array}{c}219.2 \pm 1.8^{\mathrm{B}} \\
(\mathrm{n}=42)\end{array}$ & $\begin{array}{c}1.17 \pm 0.06^{\mathrm{A}} \\
(\mathrm{n}=42)\end{array}$ \\
\hline 2 & $\begin{array}{l}\mathrm{AKR} \\
\mathrm{RF}\end{array}$ & $\begin{array}{c}239.4 \pm 4.9^{\mathrm{BC}} \\
\quad(\mathrm{n}=13)\end{array}$ & $\begin{array}{c}212.4 \pm 2.7^{\mathrm{BC}} \\
(\mathrm{n}=23)\end{array}$ & $\begin{array}{c}0.81 \pm 0.08^{\mathrm{B}} \\
\quad(\mathrm{n}=23)\end{array}$ \\
\hline 3 & $\begin{array}{l}\text { A } \\
\text { B6 } \\
\text { BALB } \\
\text { CF1 } \\
\text { KK } \\
\text { SS }\end{array}$ & $\begin{array}{c}238.1 \pm 2.3^{\mathrm{C}} \\
\quad(\mathrm{n}=88)\end{array}$ & $\begin{array}{c}209.1 \pm 1.5^{\mathrm{C}} \\
\quad(\mathrm{n}=82)\end{array}$ & $\begin{array}{c}0.81 \pm 0.04^{\mathrm{B}} \\
\quad(\mathrm{n}=82)\end{array}$ \\
\hline 4 & CAS & $\begin{array}{c}262.4 \pm 2.9^{\mathrm{A}} \\
(\mathrm{n}=12)\end{array}$ & $\begin{array}{l}234.4 \pm 1.1^{\mathrm{A}} \\
\quad(\mathrm{n}=12)\end{array}$ & $\begin{array}{l}0.81 \pm 0.11^{\mathrm{B}} \\
\quad(\mathrm{n}=12)\end{array}$ \\
\hline 5 & $\begin{array}{l}\mathrm{C} 3 \mathrm{H} \\
\mathrm{CBA} \\
\mathrm{DBA} \\
\mathrm{RR}\end{array}$ & $\begin{array}{c}251.5 \pm 2.5^{\mathrm{AB}} \\
\quad(\mathrm{n}=44)\end{array}$ & $\begin{array}{c}216.7 \pm 2.2^{\mathrm{B}} \\
\quad(\mathrm{n}=49)\end{array}$ & $\begin{array}{c}0.98 \pm 0.06^{\mathrm{AB}} \\
\quad(\mathrm{n}=44)\end{array}$ \\
\hline
\end{tabular}

a) Values with different superscripts differ significantly.

$[35,38]$. Therefore, we expect that there are no substantial defects in the spermatogenic ability in DH-Chr Y@ $\mathrm{F}_{1}$-A and $\mathrm{F}_{1}-\mathrm{Y}$ strain males, despite variation in testis weight and $\mathrm{Tw}$ ratio among strains.

In conclusion, we confirmed our previous findings that the genes on the $\mathrm{Y}$ chromosome influenced testis weight in two genetic backgrounds. We also revealed that the effect of the $A^{y}$ allele in reducing testis weight was modified by the genes on the Y chromosome. These data suggest that testis weight in mice is controlled by a cooperation of genes on autosomes and $\mathrm{Y}$ chromosome.

ACKNOWLEDGMENTS. This work was supported by Grants-in-Aid for Scientific Research from the Japan Society for the Promotion of Science (nos. 15500305 and 19500373 to JS) and NIAS Strategic Research Fund (to JS).

\section{REFERENCES}

1. Albrecht, K. H. and Eicher, E. M. 1997. DNA sequence analysis of Sry alleles (subgenus Mus) implicates misregulation as the cause of $\mathrm{C} 57 \mathrm{BL} / 6 \mathrm{~J}-\mathrm{Y}\left({ }^{\mathrm{POS}}\right)$ sex reversal and defines the SRY functional unit. Genetics 147: 1267-1277. [Medline]

2. Bishop, C. E., Boursot, P., Baron, B., Bonhomme, F. and Hatat, D. 1985. Most classical Mus musculus domesticus laboratory mouse strains carry a Mus musculus musculus Y chromosome. Nature 315: 70-72. [Medline] [CrossRef]

3. Bowles, J., Cooper, L., Berkman, J. and Koopman, P. 1999. Sry requires a CAG repeat domain for male sex determination in Mus musculus. Nat. Genet. 22: 405-408. [Medline] [CrossRef]

4. Bultman, S. J., Michaud, E. J. and Woychik, R. P. 1992. Molecular characterization of the mouse agouti locus. Cell 71: 1195-1204. [Medline] [CrossRef]

5. Carlisle, C., Winking, H., Weichenhan, D. and Nagamine, C. M.
1996. Absence of correlation between Sry polymorphisms and $\mathrm{XY}$ sex reversal caused by the M. m. domesticus Y chromosome. Genomics 33: 32-45. [Medline] [CrossRef]

6. Chen, A. S., Marsh, D. J., Trumbauer, M. E., Frazier, E. G., Guan, X. M., Yu, H., Rosenblum, C. I., Vongs, A., Feng, Y., Cao, L., Metzger, J. M., Strack, A. M., Camacho, R. E., Mellin, T. N., Nunes, C. N., Min, W., Fisher, J., Gopal-Truter, S., MacIntyre, D. E., Chen, H. Y. and Van der Ploeg, L. H. 2000. Inactivation of the mouse melanocortin-3 receptor results in increased fat mass and reduced lean body mass. Nat. Genet. 26: 97-102. [Medline] [CrossRef]

7. Chubb, C. 1992. Genes regulating testis size. Biol. Reprod. 47: 29-36. [Medline] [CrossRef]

8. Coward, P., Nagai, K., Chen, D., Thomas, H. D., Nagamine, C. M. and Lau, Y. F. C. 1994. Polymorphism of a CAG trinucleotide repeat within Sry correlates with B6.Y ${ }^{\text {Dom }}$ sex reversal. Nat. Genet. 6: 245-250. [Medline] [CrossRef]

9. Doolittle, D. P., Davisson, M. T., Guidi, J. N. and Green, M. C. 1996. Catalog of mutant genes and polymorphic loci. pp. 17-854. In: Genetic Variants and Strains of the Laboratory Mouse, 3rd ed., Vol. 1. (Lyon, M. F., Rastan, S. and Brown, S. D. M. eds.), Oxford University Press, Oxford, New York, Tokyo.

10. Duhl, D. M., Vrieling, H., Miller, K. A., Wolff, G. L. and Barsh, G. S. 1994. Neomorphic agouti mutations in obese yellow mice. Nat. Genet. 8: 59-65. [Medline] [CrossRef]

11. Eicher, E. M. 1994. Sex and trinucleotide repeats. Nat. Genet. 6: 221-223. [Medline] [CrossRef]

12. Eicher, E. M., Washburn, L. L., Whitney, J. B. 3rd. and Morrow, K. E. 1982. Mus poschiavinus Y chromosome in the C57BL/6J murine genome causes sex reversal. Science 217: 535-537. [Medline] [CrossRef]

13. Greenfield, A., Scott, D., Pennisi, D., Ehrmann, I., Ellis, P., Cooper, L., Simpson, E. and Koopman, P. 1996. An H-YD ${ }^{\mathrm{b}}$ epitope is encoded by a novel mouse Y chromosome gene. Nat. Genet. 14: 474-478. [Medline] [CrossRef]

14. Harcourt, A. H., Harvey, P. H., Larson, S. G. and Short, R. V. 
1981. Testis weight, body weight and breeding system in primates. Nature 293: 55-57. [Medline] [CrossRef]

15. Hayward, P. and Shire, J. G. M. 1974. Y chromosome effect on adult testis size. Nature 250: 498-500. [Medline] [CrossRef]

16. Herrick, C. S. and Wolfe, H. G. 1977. Effect of the Y-chromosome on testis size in the mouse (Mus musculus). Genetics $\mathbf{8 6}$ : s27.

17. Hunt, S. E. and Mittwoch, U. 1987. Y-chromosomal and other factors in the development of testis size in mice. Genet. Res. 50: 205-211. [Medline] [CrossRef]

18. Huszar, D., Lynch, C. A., Fairchild-Huntress, V., Dunmore, J. H., Fang, Q., Berkemeier, L. R., Gu, W., Kesterson, R. A., Boston, B. A., Cone, R. D., Smith, F. J., Campfield, L. A., Burn, P. and Lee, F. 1997. Targeted disruption of the melanocortin-4 receptor results in obesity in mice. Cell 88: 131-141. [Medline] [CrossRef]

19. Krausz, C., Degl'Innocenti, S., Nuti, F., Morelli, A., Felici, F., Sansone, M., Varriale, G., Forti, G. 2006. Natural transmission of USP9Y gene mutations: a new perspective on the role of AZFa genes in male fertility. Hum. Mol. Genet. 15: 2673-2681. [Medline] [CrossRef]

20. Kunieda, T. and Toyoda, Y. 1992. Nucleotide sequence of mouse Sry gene is different between $\mathrm{Y}$ chromosome originating from Mus musculus musculus and Mus musculus domesticus. Genomics 13: 236-237. [Medline] [CrossRef]

21. L'Hôte, D., Serres, C., Laissue, P., Oulmouden, A., Rogel-Gaillard, C., Montagutelli, X. and Vaiman, D. 2007. Centimorganrange one-step mapping of fertility traits using interspecific recombinant congenic mice. Genetics 176: 1907-1921. [Medline] [CrossRef]

22. Le Roy, I., Tordjman, S., Migliore-Samour, D., Degrelle, H. and Roubertoux, P. L. 2001. Genetic architecture of testis and seminal vesicle weights in mice. Genetics 158: 333-340. [Medline]

23. Lu, D., Willard, D., Patel, I. R., Kadwell, S., Overton, L., Kost, T., Luther, M., Chen, W., Woychik, R. P., Wilkison, W. O. and Cone, R. D. 1994. Agouti protein is an antagonist of the melanocyte-stimulating-hormone receptor. Nature 371: 799-802. [Medline] [CrossRef]

24. Luddi, A., Margollicci, M., Gambera, L., Serafini, F., Cioni, M., De Leo, V., Balestri, P. and Piomboni, P. 2009. Spermatogenesis in a man with complete deletion of USP9Y. N. Engl. J. Med. 360: 881-885. [Medline] [CrossRef]

25. Michaud, E. J., Bultman, S. J., Stubbs, L. J. and Woychik, R. P. 1993. The embryonic lethality of homozygous lethal yellow mice (Ay/Ay) is associated with the disruption of a novel RNA-binding protein. Genes Dev. 7 7A: 1203-1213. [Medline] [CrossRef]

26. Michaud, E. J., Bultman, S. J., Klebig, M. L., van Vugt, M. J., Stubbs, L. J., Russell, L. B. and Woychik, R. P. 1994. A molecular model for the genetic and phenotypic characteristics of the mouse lethal yellow (Ay) mutation. Proc. Natl. Acad. Sci. U.S.A. 91: 2562-2566. [Medline] [CrossRef]

27. Miller, M. W., Duhl, D. M., Vrieling, H., Cordes, S. P., Ollmann, M. M., Winkes, B. M. and Barsh, G. S. 1993. Cloning of the mouse agouti gene predicts a secreted protein ubiquitously expressed in mice carrying the lethal yellow mutation. Genes Dev. 7: 454-467. [Medline] [CrossRef]

28. Nishioka, Y. 1987. Y-chromosomal DNA polymorphism in mouse inbred strains. Genet. Res. 50: 69-72. [Medline] [CrossRef]

29. Ollmann, M. M., Wilson, B. D., Yang, Y. K., Kerns, J. A., Chen, Y., Gantz, I. and Barsh, G. S. 1997. Antagonism of central melanocortin receptors in vitro and in vivo by agouti-related protein. Science 278: 135-138. [Medline] [CrossRef]

30. Ren, D. R., Ren, J., Xing, Y. Y., Guo, Y. M., Wu, Y. B., Yang, G. C., Mao, H. R. and Huang, L. S. 2009. A genome scan for quantitative trait loci affecting male reproductive traits in a White Duroc x Chinese Erhualian resource population. J. Anim. Sci. 87: 17-23. [Medline] [CrossRef]

31. Robbins, L. S., Nadeau, J. H., Johnson, K. R., Kelly, M. A., Roselli-Rehfuss, L., Baack, E., Mountjoy, K. G. and Cone, R. D. 1993. Pigmentation phenotypes of variant extension locus alleles result from point mutations that alter MSH receptor function. Cell 72: 827-834. [Medline] [CrossRef]

32. Storchová, R., Gregorová, S., Buckiová, D., Kyselová, V., Divina, P. and Forejt, J. 2004. Genetic analysis of X-linked hybrid sterility in the house mouse. Mamm. Genome 15: 515-524. [Medline] [CrossRef]

33. Sun, C., Skaletsky, H., Birren, B., Devon, K., Tang, Z., Silber, S., Oates, R. and Page, D. C. 1999. An azoospermic man with a de novo point mutation in the Y-chromosomal gene USP9Y. Nat. Genet. 23: 429-432. [Medline] [CrossRef]

34. Suto, J. 2009. The $A^{y}$ allele at the agouti locus reduces the size and alters the shape of the mandible in mice. Proc. Jpn. Acad., Ser. B, Phys. Biol. Sci. 85: 248-257. [Medline] [CrossRef]

35. Suto, J. 2011. Quantitative trait loci that control body weight and obesity in an $\mathrm{F}_{2}$ intercross between C57BL/6J and DDD.Cg- $A^{y}$ mice. J. Vet. Med. Sci. 73: 907-915. [Medline] [CrossRef]

36. Suto, J. 2011. Genetic dissection of testis weight in mice: quantitative trait locus analysis using $\left.\mathrm{F}_{2}\right)$ intercrosses between strains with extreme testis weight, and association study using Y-consomic strains. Mamm. Genome 22: 648-660. [Medline] [CrossRef]

37. Suto, J. 2013. Y chromosome of the inbred mouse KK/Ta strain is associated with reduced body size in Y-consomic strains. BMC Res. Notes 6: 64. [Medline] [CrossRef]

38. Suto, J., Matsuura, S., Imamura, K., Yamanaka, H. and Sekikawa, K. 1998. Genetics of obesity in KK mouse and effects of $\left.A \varphi^{y}\right)$ allele on quantitative regulation. Mamm. Genome 9: 506-510. [Medline] [CrossRef]

39. Xu, J., Burgoyne, P. S. and Arnold, A. P. 2002. Sex differences in sex chromosome gene expression in mouse brain. Hum. Mol. Genet. 11: 1409-1419. [Medline] [CrossRef]

40. Zídek, V., Musilová, A., Pintír, J., Simáková, M. and Pravenec, M. 1998. Genetic dissection of testicular weight in the mouse with the BXD recombinant inbred strains. Mamm. Genome 9: 503-505. [Medline] [CrossRef] 